\title{
Feeding Value of Low and High Protein Dried Distillers Grains and Corn Gluten Meal for Layer
}

\author{
B. Tangendjaja* \& E. Wina \\ Research Institute of Animal Production (Balitnak), Ciawi \\ PO Box 221, Bogor 16002, Indonesia \\ (Received 27-09-2010; accepted 09-06-2011)
}

\begin{abstract}
ABSTRAK
Percobaan pemberian pakan telah dilakukan untuk membandingkan nilai pakan dried distillers grains with solubles (DDGS) protein rendah (Lopro) dan tinggi (Hipro) dan corn gluten meal (CGM) untuk ayam petelur cokelat di daerah tropis. Kedua jenis DDGS diberikan sebesar $0 \%, 4 \%, 8 \%$, $12 \%$, dan $16 \%$ dalam ransum, sedangkan CGM diberikan sebanyak $0 \%, 2 \%, 4 \%, 6 \%$, dan $8 \%$ dalam ransum dengan kandungan energi metabolis $(2650 \mathrm{kcal} / \mathrm{kg})$ dan protein $(17 \%)$ yang sama. Setiap perlakukan diberikan kepada 4 ekor ayam petelur dalam kandang baterai individu dan diulang 5 kali. Percobaan dilakukan selama 10 minggu dan produksi telur, berat telur, dan konsumsi pakan diukur. Kotoran ayam dikumpulkan dan dianalisa kadar airnya pada akhir percobaan, sedangkan contoh telur diukur untuk warna dan kandungan xantofilnya. Hasil percobaan menunjukkan bahwa pemberian DDGS Lopro, DDGS Hipro, dan CGM tidak mempengaruhi produksi telur (masa telur, jumlah telur, dan berat telur), akan tetapi pemberian DDGS menghasilkan konsumsi pakan (111 g/hari) yang lebih rendah dibanding ayam yang diberi CGM (114g/hari). Pemberian DDGS sampai $16 \%$ tidak mempengaruhi produksi telur, demikian pula dengan pemberian CGM sampai $8 \%$ dalam ransum. Pemberian DDGS atau CGM dalam jumlah tinggi tidak mempengaruhi kadar air kotoran yang nilainya berkisar 78,1\%-81,9\%. Pemberian DDGS atau CGM yang makin tinggi mengakibatkan kenaikan warna kuning telur yang berkaitan dengan meningkatnya kandungan xantofil di dalamnya. Pemberian CGM menghasilkan warna yang lebih kuning dibandingkan dengan pemberian DDGS. Sebagai kesimpulan, DDGS dapat diberikan sampai $16 \%$ untuk ayam petelur tanpa mempengaruhi produksi telur, sementara CGM dapat diberikan sampai $8 \%$. DDGS dapat digunakan sebagai sumber pigmen kuning untuk ayam petelur seperti halnya CGM.
\end{abstract}

Kata kunci: dried distillers grains, protein, corn gluten meal, ayam petelur, xantofil

\begin{abstract}
A feeding trial has been conducted to compare feeding value of low and high protein dried distillers grains with solubles (DDGS), and corn gluten meal (CGM) to brown layer in the tropics. Both types of DDGS was included at level $0 \%, 4 \%, 8 \%, 12 \%$, and $16 \%$ in the diet while CGM was included at $0 \%, 2 \%, 4 \%, 6 \%$, and $8 \%$ in similar content of metabolizable energy (ME) value (2650 $\mathrm{kcal} / \mathrm{kg}$ ) and protein $(17 \%)$. Each dietary treatment was fed to 4 birds in individual wire cage and replicated 5 times. The trial was performed for 10 weeks and egg production, egg weight, feed intake was measured. At the end of feeding period, manure was collected and analyzed for moisture content while samples of eggs were measured for yolk color and the yolk was analyzed for xanthophyll level. Result showed that feeding Lopro DDGS, Hipro DDGS, and CGM did not affect egg production (egg mass, egg number, and egg weight), however, feeding DDGS resulted in less feed intake (111 g/day) compared to feeding CGM (114 g/day). Feeding DDGS up to $16 \%$ did not affect egg production and similar to feeding CGM up to $8 \%$. Feeding high level of DDGS or CGM did not significantly affect the moisture content of excreta which were between $78.1 \%-81.9 \%$. Increasing levels of DDGS or CGM increased yolk color score related to the higher level of xanthophylls content in egg yolk. The coloring ability of CGM to egg yolk was higher than that of DDGS. In conclusion, DDGS can be fed to layer up to $16 \%$ without affecting egg production while CGM can be fed up to $8 \%$ in the diet. DDGS can be used as source of yellow pigment for egg yolk as also found in CGM.
\end{abstract}

Key words: dried distillers grains, protein, corn gluten meal, layer, xanthophyll

\footnotetext{
* Corresponding author:
}

budi tangendjaja@yahoo.com 


\section{INTRODUCTION}

Globally, corn becomes a major ingredient for animal feed either as whole grain or by-product from corn milling industries. There is several corn co-products derived from wet or dry corn milling industries (Tangendjaja \& Wina, 2007) and at least 2 co-products commercially available in Indonesia for poultry feed, namely corn gluten meal (CGM) and dried distillers grains and soluble (DDGS). CGM is a co-product obtained during wet milling process to produce maize starch while DDGS is a co-product obtained from dry milling process for ethanol production. CGM is a well known feed ingredient for poultry as it contains high protein level $(>60 \%)$ and high metabolizable energy (ME) (3600 kcal/kg, NRC, 1994). It has been used widely in Indonesia for many years.

When bioethanol production from corn fermentation is increasing in recent years, more DDGS are produced in the USA and exported to different countries. Therefore, DDGS is considered as a new ingredient for poultry feed in Asia including Indonesia. DDGS is the mixture of residual component after the starch of corn grain has been fermented by yeast to produce ethanol and the soluble part after the removal of ethanol by distillation (Pahm et al., 2009). Corn contains about $62 \%$ starch, $3.8 \%$ oil, $8.0 \%$ protein, $11.2 \%$ fiber, and $15 \%$ moisture. Because most of the starch is converted to ethanol during fermentation, the resulting nutrient fractions (protein, oil, and fiber) are 3 times more concentrated in DDGS compared to corn. With advance technology in ethanol production in the United States of America (USA), DDGS can be produced with higher protein level through fractionation process either in the beginning of ethanol production (front end fractionation) or at the end of ethanol production (back end fractionation). This type of DDGS will be introduced in Asian market including Indonesia and may be an attractive alternative ingredient for layer diets, however, little information on the use of high protein (Hipro) DDGS in chicken feed.

DDGS is a source of protein/amino acids, energy and available phosphorus for poultry. The regular DDGS contained protein $26.5 \%$, fat $10.8 \%$, and ME between 2787-2904 kcal/kg (Adeola \& Ileleji, 2009). However, it was reported that the nutrient contents of DDGS varied among and within ethanol plants, but nutrient levels were generally higher than those published by the National Research Council (Spiehs et al., 2002). ME of DDGS for poultry was $2848 \mathrm{kcal} / \mathrm{kg}$ (Waldroup et al., 2007) and amino acids digestibility was higher than previously reported (Batal \& Dale, 2006).

High protein DDGS contained $36 \%-45 \%$ protein with similar ME value with regular DDGS contained $25 \%-27 \%$ protein. The regular DDGS in the present experiment was considered as low protein (Lopro) DDGS since the protein content was lower compared with high protein (Hipro) DDGS.

Most of DDGS in US were derived from yellow corn and contained significant amount of carotenoids. Carotenoids consisted of xanthophylls as a source of yellow pigment and carotenes as a precursor for Vitamin A. However, little information is available on the efficacy of xanthophylls in DDGS for pigmentation of yolk color. The purpose of the trial was to determine the impact of feeding increasing levels of low (Lopro) and high protein (Hipro) DDGS compared to CGM on the performance of layer including excreta moisture and on the color of egg yolk.

\section{MATERIALS AND METHODS}

\section{Feed and Treatments}

A feeding trial to brown layer (ISA strain) was conducted at Indonesian Research Institute for Animal Production, Ciawi-Bogor with average daily temperature $28-30{ }^{\circ} \mathrm{C}$. Two types of DDGS were used, i.e the low protein (Lopro) DDGS which is actually the regular DDGS and the high protein (Hipro) DDGS. Thirteen different diets (Table 1) contain different levels of low protein DDGS. Hipro DDGS and CGM were formulated to have similar protein content $(17 \%)$ and energy level (2650 kcal/kg).

Table 1. Dietary treatments containing different levels of low protein (Lopro) DDGS, high protein (Hipro) DDGS, and CGM

\begin{tabular}{ll}
\hline Diet & Treatment \\
\hline Control & Control diet without DDGS or CGM \\
LP DDGS 4 & Diet contains Lopro DDGS 4\% \\
LP DDGS 8 & Diet contains Lopro DDGS 8\% \\
LP DDGS 12 & Diet contains Lopro DDGS 12\% \\
LP DDGS 16 & Diet contains Lopro DDGS 16\% \\
HP DDGS 4 & Diet contains Hipro DDGS 4\% \\
HP DDGS 8 & Diet contains Hipro DDGS 8\% \\
HP DDGS 12 & Diet contains Hipro DDGS 12\% \\
HP DDGS 16 & Diet contains Hipro DDGS 16\% \\
CGM 2 & Diet contains CGM 2\% \\
CGM 4 & Diet contains CGM 4\% \\
CGM 6 & Diet contains CGM 6\% \\
CGM 8 & Diet contains CGM 8\% \\
\hline
\end{tabular}

Note: $\mathrm{CGM}=$ corn gluten meal; DDGS= dried distillers grains and soluble.

Table 2. Composition of DDGS containing different protein (\%)

\begin{tabular}{lrrr}
\hline \multicolumn{1}{c}{ Component } & $\begin{array}{c}\text { Lopro } \\
\text { DDGS }\end{array}$ & $\begin{array}{r}\text { Hipro } \\
\text { DDGS }\end{array}$ & CGM \\
\hline Moisture & 9.7 & 7.38 & 10.34 \\
Protein & 26.6 & 39.60 & 60.49 \\
Fat & 9.7 & 3.92 & 1.27 \\
Crude fiber & 6.1 & 5.68 & 2.01 \\
Ash & 4.0 & 2.18 & 1.83 \\
\hline
\end{tabular}

Note: $C G M=$ corn gluten meal; DDGS= dried distillers grains and soluble; Lopro= low protein; Hipro= high protein. 
Lopro (regular) DDGS, Hipro DDGS and CGM which originated from USA, were commercially obtained. Lopro DDGS contain $27 \%$ protein while Hipro DDGS contain $40 \%$ protein and CGM contains $62 \%$ protein. The composition of the products is presented in Table 2. Other ingredients were obtained locally and these were corn, soybean meal, rice bran, crude palm oil and other supplements including minerals, amino acids, vitamin and mineral premixes. Those ingredients were mixed every month in mash form. Dietary formula and calculated nutrient composition is presented in Table 3.

\section{Feeding System}

Two hundred sixty layers at age 40 weeks were placed individually in wire cages in 1 tier of open sided house. Each dietary treatment was fed to 4 layers, placed in row as one unit of experiment and replicated 5 times, which randomly allocated in the house. Feed and water were provided ad libitum. Each unit of experiment has one feed trough and drinking water was provided for all chickens through PVC pipe. Lighting was provided for 17 hours per day. Feeding trial was conducted for 10 weeks.

\section{Measurement}

Egg production and egg weight was recorded daily and feed intake was measured every week. Total feed, total egg mass and feed conversion ratio was calculated after the experiment was completed.

Chicken excreta from each unit of experiment were collected for 24 hours on day 21 to day 22. Subsamples of excreta from chickens fed different treatments were dried in the oven to get the moisture content.

Two eggs from each unit of experiment with 5 replicates were collected every 3 days to measure egg yolk color using Roche Color Fan. Xanthophylls analysis was performed on egg yolk from each unit of experiment with 5 replicates after feeding the layer for 21 days according to the modified AOAC (Susana et al., 1993).

\section{Statistical Analyses}

Completely randomized design was used in this experiment and performance data was analyzed using general linear model. The effect of corn co-products and the effect of levels were analyzed separately. Initial analyses were done to compare the main effect of type of co-product, while separate analyses were performed for each co-product to look at the level effect. Any significant effect due to treatment was further analyzed by Duncan test. Regression analysis was performed to measure the effect of pigmenting ability of DDGS and CGM on yolk color.

\section{RESULTS AND DISCUSSION}

\section{Laying Performance}

Result on the performance of brown layer fed low protein DDGS, high protein DDGS, and CGM are presented in Table 4 . Table 4 indicates that there is no significant difference on the effect of feeding Lopro and Hipro DDGS and CGM on egg production in term of total egg mass and number, egg weight and feed conversion ratio. The laying performance is comparable to the standard recommended by ISA Brown management guide (ISA, 2010). Feed to egg ratio (FCR) is around 2 and is slightly lower than the recommended FCR in ISA brown management guide (ISA, 2010). The average egg weight at $63 \mathrm{~g}$ is also acceptable for the current age of layer in the tropics. However, daily feed intake of layer fed DDGS either low or high protein has 2-3 g less compared to that consume by layer fed CGM. Average feed intake of layer fed CGM is $113.7 \mathrm{~g} /$ day while that layer fed DDGS is around $111 \mathrm{~g} /$ day. There is no difference in feed intake between layers fed high protein or Lopro DDGS as the formula is adjusted to have similar ME, protein, and amino acids content. It is not known if less feed intake in layer fed DDGS is related to the higher fiber level in DDGS relative to CGM. NRC (1998) reported that DDGS contain 34.6\% neutral detergent fiber (NDF) and 16.3\% acid detergent fiber (ADF) while CGM contains only $8.7 \%$ and $4.6 \%$, respectively. It was well known that high fiber diet will influence the bulkiness of feed and would affect feed intake. However, the difference of feed intake 2-3 g would not be sufficient to affect laying performance.

Further analyses were conducted to evaluate the effect of inclusion level of Lopro, Hipro, and DDGS on performance of the layer and the results are presented in Table 5, 6, and 7, respectively. Generally, increasing level of DDGS both low and high protein up to $16 \%$ or CGM up to $8 \%$ did not affect egg production and feed conversion ratio. Egg number and feed per egg ratio remained stable. There was an indication that feeding Hipro DDGS resulted in a slightly lower egg weight when the DDGS was included up to $16 \%$. Egg weight of layer fed 16\% Hipro DDGS was $62.2 \mathrm{~g}$ while feeding at $4 \%$ inclusion level in the diet was $63.4 \mathrm{~g}$. There was a slight reduction (2-4 g/day) in feed intake when Lopro or Hipro DDGS was included in the diets. This result was comparable with the result reported by Lumpkins et al. (2005) that regular or Lopro DDGS can be included up to $12 \%$ in the diet of laying hen. They also reported that feeding high level $(15 \%)$ of Lopro DDGS would depress egg production in the diet with low in energy density. There is no report on feeding Hipro DDGS on layer. Swiatkiwicz \& Koreleski (2006) reported that up to $15 \%$ Lopro DDGS could be used in layer feeds while, inclusion of $20 \%$ negatively affected laying rate and egg weight. Recent report on feeding Lopro DDGS showed that feeding $15 \%-20 \%$ in the diets resulted in a lower egg production and egg weight and certain enzyme supplementation would improve the egg production so Lopro DDGS can be included up to $20 \%$ in the diets (Shalash et al., 2010).

\section{Moisture Content of Excreta}

Results on analyses of moisture content of excreta collected from layer fed control diet and different levels of Lopro and Hipro DDGS and CGM are presented in 


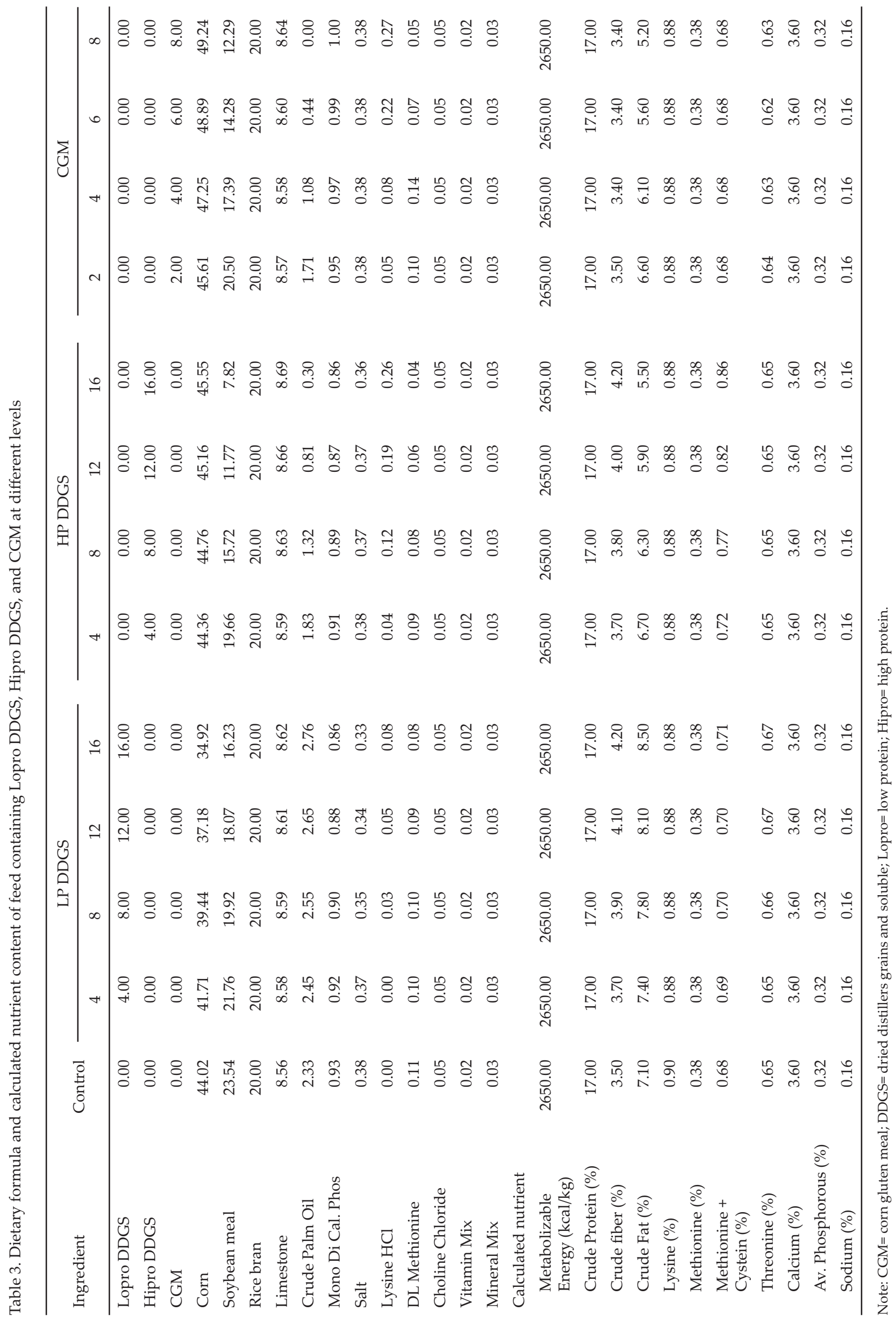


Table 4. Layer performance fed diets containing of Lopro DDGS, Hipro DDGS, and CGM in 10 weeks

\begin{tabular}{lcccccc}
\hline $\begin{array}{c}\text { Type of } \\
\text { co-product }\end{array}$ & $\begin{array}{c}\text { Total feed for 10 } \\
\text { weeks }(\mathrm{g})\end{array}$ & $\begin{array}{c}\text { Total number } \\
\text { of egg }\end{array}$ & $\begin{array}{c}\text { Total egg mass } \\
(\mathrm{g})\end{array}$ & FCR & $\begin{array}{c}\text { Egg weight } \\
(\mathrm{g})\end{array}$ & $\begin{array}{c}\text { Daily feed } \\
\text { intake }(\mathrm{g} / \text { day })\end{array}$ \\
\hline Lopro DDGS & $31,221.3^{\mathrm{b}}$ & 254.4 & $15,746.0$ & 1.953 & 62.9 & $111.5^{\mathrm{b}}$ \\
Hipro DDGS & $30,978.8^{\mathrm{b}}$ & 251.2 & $15,824.5$ & 1.959 & 63.0 & $110.6^{\mathrm{b}}$ \\
CGM & $31,849.5^{\mathrm{a}}$ & 252.1 & $15,782.8$ & 2.024 & 62.6 & $113.7^{\mathrm{a}}$ \\
Sem & 127.6 & 3.3 & 199.3 & 0.025 & 0.1 & 0.4 \\
\hline
\end{tabular}

Note: Means in the same column with different superscript differ significantly $(\mathrm{P}<0.05)$. Sem= standard error for means; CGM= corn gluten meal; DDGS= dried distillers grains and soluble; Lopro= low protein; Hipro= high protein.

Table 5. Layer performance fed diets containing of Lopro DDGS (protein 27\%) at different levels in 10 weeks

\begin{tabular}{ccccccc}
\hline Level $(\%)$ & $\begin{array}{c}\text { Total feed } \\
(\mathrm{g})\end{array}$ & $\begin{array}{c}\text { Number } \\
\text { of egg }\end{array}$ & $\begin{array}{c}\text { Total egg } \\
\text { mass }(\mathrm{g})\end{array}$ & FCR & $\begin{array}{c}\text { Egg weight } \\
(\mathrm{g})\end{array}$ & $\begin{array}{c}\text { Daily feed } \\
\text { intake }(\mathrm{g} / \text { day })\end{array}$ \\
\hline 0 & $32,320^{\mathrm{a} *}$ & 259.6 & 16,333 & 1.980 & 62.9 & $115.4^{\mathrm{a}}$ \\
4 & $31,650^{\mathrm{b}}$ & 260.8 & 16,410 & 1.930 & 62.9 & $113.0^{\mathrm{b}}$ \\
8 & $30,788^{\mathrm{c}}$ & 248.2 & 15,610 & 1.975 & 62.9 & $110.0^{\mathrm{c}}$ \\
12 & $31,714^{\mathrm{b}}$ & 253.0 & 15,773 & 2.013 & 62.4 & $113.3^{\mathrm{b}}$ \\
16 & $31,250^{\mathrm{bc}}$ & 252.4 & 15,739 & 1.989 & 62.4 & $111.6^{\mathrm{bc}}$ \\
Sem & 205 & 4.5 & 274 & 0.034 & 0.3 & 0.7 \\
\hline
\end{tabular}

Note: Means in the same column with different superscript differ significantly $(\mathrm{P}<0.05)$. Sem $=$ standard error for means; DDGS= dried distillers grains and soluble; Lopro= low protein.

Table 6. Layer performance fed diets containing of Hipro DDGS at different levels in 10 weeks

\begin{tabular}{ccccccc}
\hline Level (\%) & $\begin{array}{c}\text { Total feed } \\
(\mathrm{g})\end{array}$ & $\begin{array}{c}\text { Number } \\
\text { of egg }\end{array}$ & $\begin{array}{c}\text { Total egg } \\
\text { mass (g) }\end{array}$ & FCR & $\begin{array}{c}\text { Egg weight } \\
(\mathrm{g})\end{array}$ & $\begin{array}{c}\text { Daily feed } \\
\text { intake (g/day) }\end{array}$ \\
\hline 0 & $32,320^{\mathrm{a}}$ & 259.6 & $16,333^{\mathrm{a}}$ & 1.980 & $62.9^{\mathrm{ab}}$ & $115.4^{\mathrm{a}}$ \\
4 & $31,146^{\mathrm{b}}$ & 252.8 & $16,033^{\mathrm{ab}}$ & 1.944 & $63.4^{\mathrm{a}}$ & $111.2^{\mathrm{b}}$ \\
8 & $31,046^{\mathrm{b}}$ & 250.6 & $15,775^{\mathrm{ab}}$ & 1.968 & $63.0^{\mathrm{ab}}$ & $110.9^{\mathrm{b}}$ \\
12 & $31,198^{\mathrm{b}}$ & 248.6 & $15,543^{\mathrm{ab}}$ & 2.019 & $62.3^{\mathrm{b}}$ & $111.4^{\mathrm{b}}$ \\
16 & $31,042^{\mathrm{b}}$ & 249.6 & $15,494^{\mathrm{b}}$ & 2.000 & $62.2^{\mathrm{b}}$ & $110.9^{\mathrm{b}}$ \\
Sem & 152 & 4.2 & 257 & 0.035 & 0.2 & 0.5 \\
\hline
\end{tabular}

Note: Means in the same column with different superscript differ significantly $(\mathrm{P}<0.05)$. Sem= standard error for means; DDGS= dried distillers grains and soluble; Hipro= high protein.

Table 7. Layer performance fed diets containing of corn gluten meal at different level in 10 weeks

\begin{tabular}{|c|c|c|c|c|c|c|}
\hline Level (\%) & $\begin{array}{l}\text { Total feed } \\
\quad(\mathrm{g})\end{array}$ & $\begin{array}{l}\text { Number } \\
\text { of egg }\end{array}$ & $\begin{array}{l}\text { Total egg } \\
\text { mass (g) }\end{array}$ & FCR & $\begin{array}{l}\text { Egg weight } \\
\text { (g) }\end{array}$ & $\begin{array}{c}\text { Daily feed } \\
\text { intake (g/day) }\end{array}$ \\
\hline 0 & 32,320 & 259.6 & 16,333 & 1.980 & $62.9^{\mathrm{ab}}$ & $115.4^{\mathrm{a}}$ \\
\hline 2 & 31,850 & 255.0 & 16,151 & 1.974 & $63.3^{\mathrm{a}}$ & $113.8^{\mathrm{ab}}$ \\
\hline 4 & 32,086 & 245.4 & 15,509 & 2.079 & $63.2^{\mathrm{a}}$ & $114.6^{\mathrm{ab}}$ \\
\hline 6 & 31,332 & 252.4 & 15,867 & 1.979 & $62.9^{\mathrm{ab}}$ & $111.9^{\mathrm{b}}$ \\
\hline 8 & 31,728 & 259.4 & 16,150 & 1.965 & $62.3^{\mathrm{b}}$ & $113.3^{\mathrm{ab}}$ \\
\hline Sem & 266 & 6.1 & 367 & 0.045 & 0.2 & 1.0 \\
\hline
\end{tabular}

Note: Means in the same column with different superscript differ significantly $(\mathrm{P}<0.05)$. Sem= standard error for means.

Table 8. Moisture content of excreta ranged from $77.4 \%$ to $84.3 \%$. Visual observation showed that there was no indication of wet excreta in this trial.
Table 8 shows that there is no difference in excreta moisture content among treatments. Increasing level of corn by-products in the diets did not influence the 
moisture content of layer excreta. One should pay some attention when moisture content of excreta increased as it is related to "wet litter" problem in poultry production and may relate to the diet composition or feeding specific ingredient (Shane, 1999). Wet litter will more likely promote the growth and proliferation of pathogenic bacteria and molds, hence, affecting chicken health. Wet litter is also the primary cause of ammonia emissions, one of the most serious performance and environmental factors negatively affecting poultry production (Ritz et al., 2005). It has been reported that feeding DDGS decreased ammonia and hydrogen sulfide emission from excreta (Robert et al., 2007; Wu-Haan et al., 2010). This may be related with lower $\mathrm{pH}$ of excreta from layer fed DDGS (Robert et al., 2007). The final result of feeding Lopro or Hipro DDGS did not cause any adverse effect to laying performance.

\section{Xanthophyll Content and Color Score of Egg Yolk}

The xanthophylls content and the color score of egg yolk produced by layer that have been fed different levels of Lopro and Hipro DDGS and CGM are presented in Figure 1. There were linear increases in xantophyll content as the levels of CGM or DDGS increased (Figure 1, left), however, the degree of increase was affected by the type of corn co-products. Based on the coefficient regression, it was shown that coefficient for CGM is 3.85 while for low and high protein DDGS are 2.07 and 1.55, respectively. These figures indicate that CGM is more effective to provide xantophyll content to egg yolk compared to both DDGS. Xanthophyll is a source of yellow pigment for egg yolk color. The yellow color of egg yolk usually comes from yellow corn which is included about $50 \%$ in the diet. The xanthophylls in corn are called lutein and zeaxanthin. The yolk color will get more pronounced when other source of pigment such as CGM, DDGS or leaf meal is added (Leeson \& Caston, 2004). The same result occurred in this experiment where increasing levels of DDGS and CGM increased the xanthophylls content in yolk, hence, improved the color of egg yolk. CGM has more pronounced effect on the yolk color than Lopro or Hipro DDGS, although its inclusion level is less (half) than that of DDGS. This result was as expected because the xantophyll level in CGM was 130 ppm while DDGS was only $59 \mathrm{ppm}$. The increased yolk color due to DDGS was in agreement with other experiments using Lopro (regular) DDGS which led to a significantly darker and redder yolk (Roberson et al., 2005; Loar et al., 2010). Further test panels, consumers slightly preferred the eggs derived from DDGS-fed hens over eggs that were obtained from hens fed no DDGS (Loar et al., 2010).

Table 8. Moisture content of layer excreta fed diets containing of Lopro and Hipro DDGS and CGM

\begin{tabular}{|c|c|c|c|c|c|c|c|c|}
\hline \multirow{2}{*}{ Diet } & \multicolumn{7}{|c|}{ Level of inclusion (\%) } & \multirow{2}{*}{ Average } \\
\hline & 0 & 2 & 4 & 6 & 8 & 12 & 16 & \\
\hline Control & $78.1 \pm 2.0$ & & & & & & & 78.1 \\
\hline Lopro DDGS & & & $79.5 \pm 1.7$ & & $80.5^{+} 2.9$ & $80.7 \pm 1.2$ & $78.9 \pm 1.1$ & 79.9 \\
\hline Hipro DDGS & & & $84.3 \pm 0.2$ & & $83.1 \pm 0.9$ & $80.9 \pm 0.7$ & $77.4 \pm 1.4$ & 81.4 \\
\hline CGM & & $81.4 \pm 1.4$ & $80.3 \pm 1.4$ & $84.0 \pm 3.0$ & $81.8 \pm 3.3$ & & & 81.9 \\
\hline
\end{tabular}

Note: Means in the same column with different superscript differ significantly $(\mathrm{P}<0.05)$. Sem= standard error for means; CGM= corn gluten meal; DDGS= dried distillers grains and soluble; Lopro= low protein; Hipro= high protein.
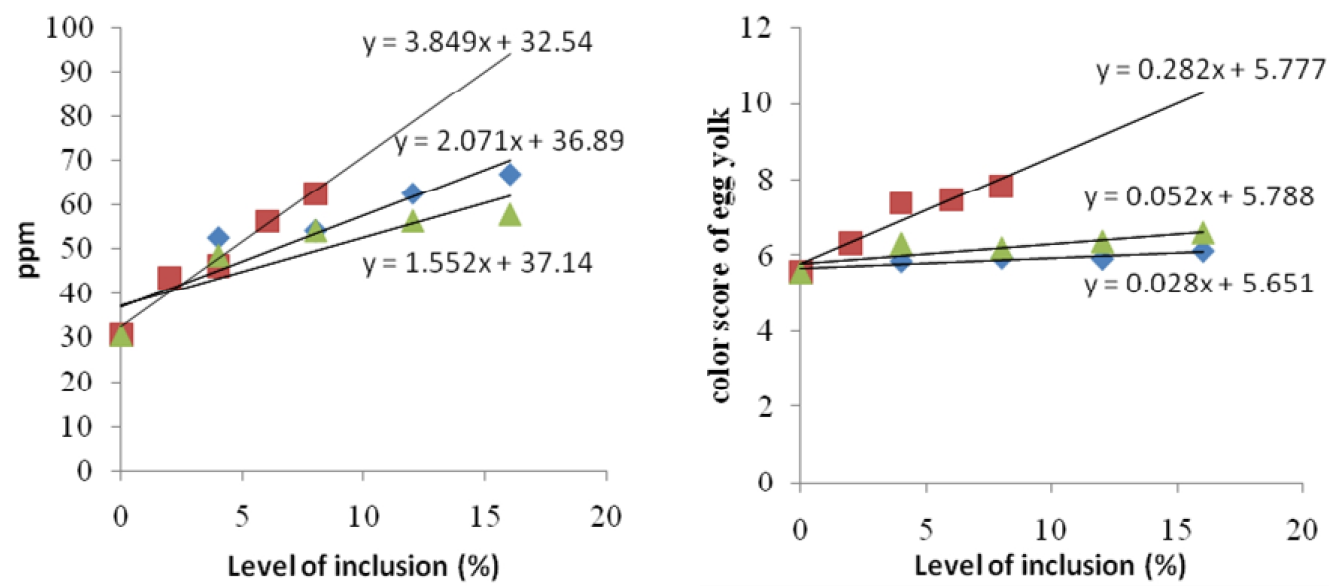

Figure 1. Xanthophyll content (left figure) and color score (based on Roche Fan) of egg yolk (right figure) fed different levels of Lopro $(\bullet)$, Hipro DDGS $(\boldsymbol{\Delta})$, and CGM $(\boldsymbol{\bullet})$ in the diet. CGM= corn gluten meal; DDGS= dried distillers grains and soluble; Lopro= low protein; Hipro= high protein. 


\section{CONCLUSION}

Dried distillers grain with soluble (DDGS) both low and high protein can be fed to layer up to $16 \%$ without detrimental effect on egg production and other performance, while corn gluten meal (CGM) can be fed up to $8 \%$ in the diet. Inclusion of DDGS (Lopro or Hipro) and CGM up to $16 \%$ and $8 \%$ in layer diet, respectively did not affect the moisture content of excreta. Increasing levels of DDGS and CGM in layer diet improved yolk color and increased the xantophyll content in the yolk. CGM is more effective than DDGS in providing xanthopyll to egg yolk resulted in higher color score.

\section{ACKNOWLEDGEMENTS}

We would like to acknowledge the support of the US Grains Council for this experiment.

\section{REFERENCES}

Adeola, O. \& K. E. Ileleji. 2009. Comparison of two diet types in the determination of metabolizable energy content of corn distillers dried grains with solubles for broiler chickens by the regression method. Poult. Sci. 88: 579-585.

Batal, A. B. \& N. M. Dale. 2006. True metabolizable energy and amino acid digestibility of distillers dried grains with solubles. J. Appl. Poult. Res. 15: 89-93.

ISA. 2010. ISA Brown commercial management guide. www. isapoultry.com (30 Juni 2010).

Leeson, S. \& L. Caston. 2004. Enrichment of eggs with lutein. Poult. Sci. 83: 1709-1712.

Loar, R. E., II, M. W. Schilling, C. D. McDaniel, C. D. Coufal, S. F. Rogers, K. Karges, \& A. Corzo. 2010. Effect of dietary inclusion level of distillers dried grains with solubles on layer performance, egg characteristics, and consumer acceptability. J. Appl. Poult. Res. 19: 30-37.

Lumpkins, B. S., A. B. Batal, \& N. M. Dale. 2005. Use of distillers dried grains plus solubles in laying hen diets. J. Appl. Poult. Res. 14: 25-31.

National Research Council. 1994. Nutrient Requirements of Poultry. 9th Revised Edition. National Academy Press, Washington DC.

National Research Council. 1998. Nutrient Requirements of Pig. 10th Revised Edition. National Academy Press, Washington, DC

Pahm, A. A., C. S. Scherer, J. E. Pettigrew, D. H. Baker, C. M. Parsons, \& H. H. Stein. 2009. Standardized amino acid digestibility in caecectomized roosters and lysine bioavailability in chicks fed distillers dried grains with solubles. Poult. Sci. 88: 571-578.

Ritz, C. W., B. B. D. Fairchild, \& M. P. Lacy. 2005. Litter Quality and Broiler Performance. Extension Poultry Scientists, University of Georgia. http://www.thepoultrysite. com/articles/388/litter-quality-and-broiler-performance (2 August 2010).

Roberson, K. D., J. L. Kalbfleisch, W. Pan. \& R. A. Charbeneau. 2005. Effect of corn distillers' dried grains and soluble at various levels on performance of laying hens and egg yolk color. Int. J. Poult. Sci. 4:44-51.

Roberts, S. A., H. Xin, B. J. Kerr, J. R. Russell, \& K. Bregendahl. 2007. Effects of dietary fiber and reduced crude protein on ammonia emission from laying-hen manure. Poult. Sci. 86:1625-1632.

Shalash, S. M. M, S. A. El-Wafa, R. A. Hassan, N. A. Ramadan, M. S. Mohamed, \& H. E. El-Gabry. 2010. Evaluation of distillers dried grains with solubles as feed ingredient in laying hen diet. Int. J. Poult. Sci. 9: 537-545.

Shane, S. 1999. Cause and Prevention of Wet Litter. ASA Technical Bulletin no 081899. ASA IM Liat Tower, Singapore.

Spiehs, M. J., M. H. Whitney, \& G. C. Shurson. 2002. Nutrient database for distiller's dried grains with solubles produced from new ethanol plants in Minnesota and South Dakota. J. Anim. Sci. 80:2639.

Susana, I. W. R, E. Wina, \& B. Tangendjaja. 1993. Quantitative analysis of carotenoid from leaves, chicken feed, egg and liver. Prosiding Nasional Seminar. Balai Penelitian Ternak.

Swiatkiwicz, S. \& J. Koreleski. 2006. Effect of maize distillers dried grains with solubles and dietary enzyme supplementation on the performance of laying hens. J. Anim. Feed Sci., 15: 253-260

Tangendjaja, B. \& E. Wina. 2007. Limbah Tanaman dan Produk Samping Industri Jagung untuk Pakan. Dalam: Sumarno, Suyamto, A. Widjono, Hermanto, \& H. Kasim (ed.). Jagung : Teknik Produksi dan Pengembangan. Pusat Penelitian dan Pengembangan Tanaman Pangan. Badan Penelitian dan Pengembangan Pertanian, Bogor. pp. 427-455.

Waldroup, P. W., Z. Wang, C. Coto, S. Cerrate, \& F. Yan. 2007. Development of a standardized nutrient matrix for corn distillers dried grains with solubles. Int. J. Poult. Sci. 6: 478-483.

Wu-Haan, W., W. Powers, R. Angel, \& T. J. Applegate. 2010. The use of distillers dried grains plus solubles as a feed ingredient on air emissions and performance from laying hens. Poult. Sci. 89:1355-1359 